\title{
Transcription of platelet-derived growth factor receptor $\alpha$ in Leydig cells involves specificity protein 1 and 3
}

\author{
Francis Bergeron ${ }^{1}$, Edward T Bagu ${ }^{1}$ and Jacques $\mathrm{J}$ Tremblay ${ }^{1,2}$ \\ ${ }^{1}$ Reproduction, Perinatal and Child Health, CHUQ Research Centre, CHUL Room T1-49, 2705 Laurier Boulevard, Québec, Québec, Canada G1V 4G2 \\ ${ }^{2}$ Department of Obstetrics and Gynecology, Faculty of Medicine, Centre for Research in Biology of Reproduction, Université Laval, Québec, Québec, Canada G1V 0A6 \\ (Correspondence should be addressed to J J Tremblay; Email: jacques-j.tremblay@crchul.ulaval.ca)
}

\begin{abstract}
Platelet-derived growth factor (PDGF) A is secreted by Sertoli cells and acts on Leydig precursor cells, which express the receptor PDGFRA, triggering their differentiation into steroidogenically active Leydig cells. There is, however, no information regarding the molecular mechanisms that govern Pdgfra expression in Leydig cells. In this study, we isolated and characterized a $2 \cdot 2 \mathrm{~kb}$ fragment of the rat $P$ dgfra $5^{\prime}$-flanking sequence in the TM3 Leydig cell line, which endogenously expresses Pdgfra. A series of $5^{\prime}$ progressive deletions of the Pdgfra promoter was generated and transfected in TM3 cells. Using this approach, two regions $(-183 /-154$ and $-154 /-105)$, each conferring $46 \%$ of Pdgfra promoter activity, were identified. To better define the regulatory elements, trinucleotide mutations spanning the $-154 /-105$ region were introduced by site-directed mutagenesis in the context of the $-2 \cdot 2 \mathrm{~kb}$ Pdgfra promoter. Mutations that altered the TCCGAGGGAAAC sequence at $-138 \mathrm{bp}$ significantly decreased Pdgfra promoter activity in TM3 cells. Several proteins from TM3 nuclear extracts were found to bind to this $G(C / A)$ motif in electromobility shift assay. Two of the proteins were identified as the transcription factors SP1 and SP3. Using transient transfections of TM3 Leydig cells, SP1 and SP3 were found to activate the Pdgfra promoter by threefold. The SP1/SP3-dependent activation of the Pdgfra promoter was severely blunted when the $\mathrm{G}(\mathrm{C} / \mathrm{A})$ motif was mutated. Our study provides new insights into the regulatory mechanisms of Pdgfra transcription in Leydig cells, which includes a role for the transcription factors SP1 and SP3.
\end{abstract}

Journal of Molecular Endocrinology (2011) 46, 125-138

\section{Introduction}

In mammalian males, there are two distinct populations of Leydig cells present in the testicular interstitium that are responsible for the production of testosterone: the fetal (FLC) and adult (ALC) Leydig cells (reviewed in Haider (2004)). During the embryonic period, the FLC produces androgens essential for masculinization of the male fetus (reviewed in Haider (2004)). Dysfunction or absence of the FLC leads to pseudohermaphrodism. During the early postnatal period, the FLC regress and are substituted by the ALC derived from undifferentiated stem cells (Ge et al. 2006). The ALC produce testosterone that is indispensable for the completion of sexual differentiation and reproductive function in males.

It has been suggested that FLC and ALC are derived from undifferentiated primordial stem cells. However, the origin of the primordial stem cells and consequently the Leydig cells remains unclear. Two sources have been proposed: the mesoderm (mesonephrogenic mesenchyme or coelomic epithelium) (Buehr et al. 1993, Karl \& Capel 1998, Merchant-Larios \& MorenoMendoza 1998, Schmahl et al. 2000) and ectoderm (neural crest) (Mayerhofer et al. 1992, Davidoff et al.
2004, Lobo et al. 2004). Both theories are consistent with the mesenchymal-like morphology of the Leydig stem cells. Differentiation of the primordial stem cells into Leydig cells is a crucial step of the male sex differentiation process. Several signaling molecules are known to initiate the differentiation of Leydig cells such as the platelet-derived growth factor A (PDGFA) secreted by Sertoli cells and its receptor PDGFRA present on Leydig cell progenitors (reviewed in Cool \& Capel (2009)). Disruption of the Pdgfa (Pdgfa $a^{\text {tm1Cbet }}$ $\left.P d g f a^{\text {tm1Cbet }}\right)$ or Pdgfra (Pdgfra $\left.{ }^{\text {tm1Sor }} / P d g f r a^{\text {tm1Sor }}\right)$ gene in mice (Gnessi et al. 2000, Brennan et al. 2003, Schmahl et al. 2008) was shown to impair the differentiation of Leydig cells (reviewed in Basciani et al. (2010)). Leydig precursor cells, or Leydig stem cells (Ge et al. 2006), are present but they fail to differentiate into steroidogenically active Leydig cells (reviewed in Basciani et al. (2010)). Despite the importance of PDGFRA in Leydig cell differentiation, there is no information regarding the molecular mechanisms that regulate its expression in Leydig cells. However, in vascular smooth muscle cells (VSMC), expression of the rat $P d g f r a$ gene is under the positive regulatory influence of the transcription factor specificity protein 1 (SP1; Bonello \& Khachigian 2004).

DOI: 10.1530/JME-10-0145 Online version via http://www.endocrinology-journals.org 
SP1 and SP3 are ubiquitously expressed transcription factors with a DNA-binding domain composed of three zinc fingers like all members of the SP family. SP1 and SP3 activate gene expression by binding to GA-, GT-, and GC-rich motifs in the regulatory region of target genes (reviewed in Li et al. (2004)). SP factors contribute to tissue- and cell-specific gene expression by functionally interacting with other tissue-restricted transcription factors (Li et al. 2004). In Leydig cells, SP1 was shown to regulate the transcription of genes encoding the $\mathrm{LH}$ receptor (Nikula et al. 2001), the nuclear receptor NR5A1 (SF1) (Scherrer et al. 2002), the angiogenic factor VEGF (Schwarzenbach et al. 2004), the acyl-CoA synthetase (Sheng et al. 2005), and the cholesterol transporter TSPO (Giatzakis et al. 2007).

In the present study, we characterized the rat Pdgfra promoter in Leydig cells. Transfections of TM3 Leydig cells revealed the presence of two regions critical for Pdgfra promoter activity. These regions were recognized by several nuclear proteins, two of which being SP1 and SP3. We report that SP1 and SP3 bind to and activate the Pdgfra promoter through a novel $\mathrm{G}(\mathrm{C} / \mathrm{A})$ motif at -138 bp.

\section{Materials and methods}

\section{Cell culture}

The mouse (TM3, mLTC-1) and rat (LC-540) Leydig cell lines were obtained from American Type Culture Collection (Manassas, VA, USA) and grown as recommended by the vendor. The mouse MA-10 Leydig cell line was provided by Dr Mario Ascoli (University of Iowa, Iowa City, IA, USA) (Ascoli 1981) and cultured in Waymouth's MB752/1 media (Sigma-Aldrich Canada) supplemented with $15 \%$ horse serum (Invitrogen Canada). All cell lines were supplemented with gentamycin/streptomycin sulfate $(50 \mathrm{mg} / \mathrm{l})$ and incubated at $37^{\circ} \mathrm{C}$ under $5 \% \mathrm{CO}_{2}$.

\section{RNA isolation, reverse transcription, PCR, and real-time PCR}

Total RNA from adult mouse testis and primary Leydig cells from immature rats (prepared as described in Martin et al. (2008)) was isolated using TRIzol (Invitrogen Canada) followed by phenol/chloroform extractions and isopropanol precipitation. The RNA pellet was then washed in $75 \%$ ethanol before it was dissolved in RNase-free water. All animal experiments were carried out in accordance with the rules and regulations set by the Canadian Council for Animal Care and the policies and procedures of the Laval University Institutional Animal Care Committee and were approved by the Animal Care and Ethics
Committee of Laval University (protocol \# 06-059). Total RNA from Leydig cell lines, TM3, LC-540, mLTC-1, and MA-10, was extracted using the RNAeasy Plus Kit (Qiagen) according to the manufacturer's recommendations. An aliquot of the total RNA ( $5 \mu \mathrm{g})$ was then used as a template to synthesize the first-strand cDNA using the Transcriptor Reverse Transcriptase (Roche Diagnostics). One tenth of the first-strand cDNA was used as a template in the real-time PCRs (qPCR). qPCRs were performed using a LightCycler 1.5 instrument and the LightCycler FastStart DNA Master SYBR Green I kit (Roche Diagnostics) according to the manufacturer's protocol. qPCRs were performed using the Pdgfra-specific primers (Table 1) and the previously described Rpl19-specific primers (Guigon et al. 2005). The PCRs were done using the following conditions: 10 min at $95{ }^{\circ} \mathrm{C}$ followed by 40 cycles of denaturation $\left(5 \mathrm{~s}\right.$ at $\left.95^{\circ} \mathrm{C}\right)$, annealing $\left(5 \mathrm{~s}\right.$ at $59^{\circ} \mathrm{C}$ for Pdgfra and $62{ }^{\circ} \mathrm{C}$ for Rpl19 cDNAs), and extension (10 s for Pdgfra and $20 \mathrm{~s}$ for $R p l 19$ at $72^{\circ} \mathrm{C}$ ) with single acquisition of fluorescence at the end of each extension steps. The specificity of PCR products was confirmed by analysis of the melting curve, agarose gel electrophoresis, and by sequencing (Centre de génomique de Québec, CHUQ). Quantification of gene expression was performed using the Relative Quantification Software (Roche Diagnostics) and is expressed as a ratio of Pdgfra to Rpl19 mRNA levels. Each amplification was performed in duplicate using a pool of three different preparations of first-strand cDNAs for each of the three different RNA extractions. The expression of HLTF, RBPJ-K, HMX2, MYT1, and NFAT family members in a panel of Leydig cell lines was determined by PCR using oligonucleotides listed in Table 1.

\section{Plasmids}

A $2185 \mathrm{bp}$ fragment $(-2170$ to $+14 \mathrm{bp})$ of the $5^{\prime}$ flanking sequence of the rat Pdgfra gene was generated from rat genomic DNA by PCR using the primers listed in Table 1. A series of $5^{\prime}$ progressive deletion constructs $(-514,-243,-183,-154,-105,-71$, and $-50 \mathrm{bp})$ were generated using the primers listed in Table 1 and the -2170 to +14 bp Pdgfra plasmid as template. All the Pdgfra promoter fragments were cloned into a modified pXP1 luciferase reporter plasmid (Tremblay \& Viger 1999) and verified by sequencing and digestion with restriction enzymes. Site-directed serially arranged trinucleotide mutations were introduced between -154 and $-105 \mathrm{bp}$ of the -2170 to +14 bp promoter sequence of the rat Pdgfra construct using the QuikChange II XL mutagenesis kit (Stratagene, La Jolla, CA, USA) and the oligonucleotides listed in Table 1. Expression vectors encoding rat HMX2 and RBPJ-K and the mouse HLTF proteins were obtained by cloning the corresponding full-length cDNA, which 
Table 1 Oligonucleotides used in the study of the rat Pdgfra promoter

Application

Real-time PCR

Pdgfra

Rp/19

Pdgfra promoter

Mutagenesis

EMSA

ChIP

cDNA/PCR and cloning

RBPJ-K
MYT1
HMX2
NFATC1
NFATC2
NFATC3
NFATC4
NFAT5

Sequence $^{a}$

Forward: 5'-CAATCCAAAGATGTCCAGGTC-3' Reverse: $5^{\prime}$-ACCAAGTCAGGTCCCATTTAC-3'

Forward: 5'-CTGAAGGTCAAAGGGAATGTG-3' Reverse: $5^{\prime}$-GGACAGAGTCTTGATGATCTC-3' 5'-GCTGGGTCCCGACTCAGCGAGATCT-3' 5'-CGGGATCCGGCCATATTTCTAGCGAGGCCC-3' 5'-CGGGATCCTTGTTGAAGTCTGGGGGTTGGG-3' $5^{\prime}$-GAAGATCTAGAGGTCTGAGCCTGAGAG-3' 5'-GAAGATCTCAAGGAGGAGTCCGAGGGAAAC-3' 5'-GAGGATCTGGGGACTTCATTTCCTGACAGCTA-3' 5'-GAAGATCTGCAAATGATTAGTTTTCGGAG-3' $5^{\prime}$-GAAGATCTGATGGACTATAACATTGAATC-3' 5'-ACGCGTCGACTCAAGCTCCAACAGTAATGGGCTC-3'

S: 5'-GCDTGAGAGGTTCAGAGAtaCAGGAGGAGTCCGAGGG-3' S: $5^{\prime}$-CCTGAGAGGTTCAGAGAGCAAttcGGAGTCCGAGGGA-3' S: 5'-GAGAGGTTCAGAGAGCAAGGAGtctTCCGAGGGAAACTT-3' S: 5'-GAGAGCAAGGAGGAGTaatAGGGAAACTTTTATTTTGAAGAGACC-3' S: 5'-GAGAGCAAGGAGGAGTCCGAtttAAACTTTTATTTTGAAGAGACC-3 S: 5'-GCAAGGAGGAGTCCGAGGGAcctTTTTATTTTGAAGAGACCAGGG-3' S: 5'-GGAGTCCGAGGGAAACTgggATTTTGAAGAGACCAGGGG-3' S: $5^{\prime}$-GGAGTCCGAGGGAAACTTTTAgggTGAAGAGACCAGGGGGGGGG-3' S: 5'-GTCCGAGGGAAACTTTTATTTTTtccGAGACCAGGGGGGGG-3' S: 5'-GGGAAACTTTTATTTTGAAGctcCCAGGGGGGGGGGAC-3'

S: 5'-GGGAAACTTTTATTTTGAAGAGACactGGGGGGGGGACTTC-3'

S: $5^{\prime}$-TTTGAAGAGACCAGGtttGGGGGACTTCATTTCCTGACAG-3'

S: 5'-GAGCAAGGAGGAGTCCGAGGGAAACTTTTAT-3'

S: 5'-TCCGAGGGAAACTTTTATTTTGAAGAGACCAGG-3'

S: $5^{\prime}$-GAGCAAaagGGAGTCCGAGGGAAACTTTTAT-3'

S: 5'-GAGCAAGGAGtctTCCGAGGGAAACTTTTAT-3'

S: 5'-GAGCAAGGAGGAGTaatAGGGAAACTTTTAT-3'

S: 5'-GAGCAAGGAGGAGTCCGAtttAAACTTTTAT-3'

S: $5^{\prime}$-TCCGAGGGAcctTTTTATTTTGAAGAGACCAGG-3'

S: 5'-TCCGAGGGAAACTgggATTTTGAAGAGACCAGG-3'

S: 5'-TCCGAGGGAAACTTTTAgggTGAAGAGACCAGG-3'

S: $5^{\prime}$-TCCGAGGGAAACTTTTATTTTaggGAGACCAGG-3'

S: 5'-TCCGAGGGAAACTTTTATTTTGAAGctcCCAGG-3'

S: 5'-CGGCGCAGGGCGGGGCGGGGCGAG-3'

S: 5'-AGAAAAGGGAATATTTACTTATCCCACCAA-3'

S: 5'-GGAAACACGCCGTGGGAAAAAAATTTGGG-3'

S: 5'-CAACAGGCTCGCGCGGAGACAAAGGGGCTGGC-3'

S: 5'-ATCAGTTGGAAGTTTCCAGGACATCTTC-3'

S: 5'-GACTGACACACTATAAACGGCATGGATT-3'

S: 5'-TTCAAGGGAAACGTTTCGCGC-3'

S: 5'-TGGAAAATTTGTTTCATAGT-3'

AS: $5^{\prime}$-CAAGCTCCAACAGTAATGGGC-3'

S: $5^{\prime}$-GAGAGGTCTGAGCCTGAGAG-3'

AS: 5'-GGGGTACCATGTCCTATACGTTCACGAGG-3'

S: 5'-GCTCTAGATTACAAGTCAATTAAAGTTCTG-3'

AS: 5'-GCTCTAGAAAGATGGCGCCTGTTGTGACAG-3'

S: 5'-CGGGATCCTTAGGACACCACGGTTGCTGTG-3'

AS: $5^{\prime}$-GGGGTACCATGAGCTCAGAAAGTGATGAC-3'

S: 5'-CGGAATTCCTAGACCTGAATGCCCCTCAC-3'

AS: $5^{\prime}$-GCTCTAGAAGGATGGGCAGCAAGGAAGATG-3'

S: 5'-CGGGATCCTCAGTAGTCAAGCTTGTTGTAC-3'

AS: 5'-TATATGAGCCCATCCTTGCC-3'

S: 5'-AACGGGATCTCCAGGACTTT-3'

AS: 5'-ATGTGAGCAGGAGGAGAGGA-3'

S: $5^{\prime}$-TCATCTGCTGTCCCAATGAA-3'

AS: 5'-GCATTCTGGACAGCACTCAA-3'

S: $5^{\prime}$-TGGCTTGGGAAACAGAAATC-3'

AS: $5^{\prime}$-TCCTTATCTGTCAGAAGGCTTTGG-3'

S: $5^{\prime}$-GTCTCGGCCAATGATCTCACTCAC-3'

AS: 5'-GCTTTCTCAGCTTACCACGG-3'

S: $5^{\prime}$-TGCAACACCACTGGTTCATT-3'

S, sense; AS, antisense.

${ }^{a}$ Cloning sites are underlined while mutations are in lower caps. 
were obtained by RT-PCR using the oligonucleotides listed in Table 1, in the pcDNA3 expression vector (Invitrogen). The mouse SP1 expression vector was obtained from Dr Robert Viger (CHUQ Research Centre, Laval University, Quebec, Canada), whereas the mouse SP3 expression vector was obtained from the Mammalian Gene Collection (Invitrogen).

\section{Transfections and luciferase assays}

Transient transfections of TM3 Leydig cells were performed in 24-well plates using the calcium phosphate co-precipitation method (Martin \& Tremblay 2005). Briefly, on the day before transfection, 30000 TM3 Leydig cells were seeded with $500 \mu \mathrm{l}$ of media per well in 24-well plates. Four hours prior to transfection, the media were replaced with fresh media $(500 \mu \mathrm{l} /$ well $)$. Cells were then transfected with $500 \mathrm{ng}$ of rat Pdgfra reporter construct (Firefly Luciferase) along with $10 \mathrm{ng}$ of phRL-TK (Renilla Luciferase) and $990 \mathrm{ng}$ of pSP64 plasmid to adjust the total amount of DNA to $1.5 \mu \mathrm{g} /$ well. The phRL-TK plasmid was used as an internal control for transfection efficiency. The media were replaced with fresh media $(500 \mu \mathrm{l} /$ well $) 12-16 \mathrm{~h}$ after transfection. The TM3 Leydig cells were lysed 36-40 h following transfection, and the Dual-Luciferase Assay System (Promega Corporation) was used to measure luciferase activities (firefly and renilla) using a Luminoskan Ascent luminometer (Thermo Scientific, Waltham, MA, USA). Data reported represent an average of at least three experiments, each done in triplicate, using at least three different DNA preparations. When evaluating the effect of SP1, SP3, HLTF, RBPJ-K, and HMX2 on the Pdgfra promoter, the TM3 Leydig cells were co-transfected with $250 \mathrm{ng}$ of either an expression vector encoding the corresponding full-length protein or an empty vector as control in addition to the Pdgfra reporters and phRL-TK internal control. The total amount of DNA was maintained at $1.5 \mu \mathrm{g} /$ well by adding $740 \mathrm{ng}$ pSP64 plasmid.

\section{Electromobility shift assays}

TM3 Leydig cells were scrapped off the Petri dish $(100 \mathrm{~mm})$ using $1.5 \mathrm{ml}$ of PBS-EDTA $(1 \mathrm{mM})$ and then centrifuged at $3500 \mathrm{~g}$ for $60 \mathrm{~s}$ at room temperature. Nuclear extracts were isolated according to the method described by Schreiber et al. (1989). For electromobility shift assay (EMSA), two probes were obtained by $5^{\prime}$ labeling with ${ }^{32} \mathrm{P}$ double-stranded oligonucleotides corresponding to two regions $(-157 /-127$ and $-144 /-112 \mathrm{bp}$ ) of the Pdgfra promoter (sequences provided in Table 1). Each probe (50000 c.p.m.) was incubated with $5 \mu \mathrm{g}$ of nuclear extracts from TM3 Leydig cells in $20 \mu \mathrm{l}$ of $4 \mathrm{mM}$ Tris- $\mathrm{HCl}$ ( $\mathrm{pH} 8 \cdot 0$ ),
$24 \mathrm{mM}$ KC1, $0.5 \mathrm{mM}$ EDTA ( $\mathrm{pH} 8 \cdot 0$ ), $0 \cdot 4 \mathrm{mM}$ dithiothreitol, $5 \mathrm{mM} \mathrm{MgCl}_{2}, 6 \%$ glycerol, and $1 \mu \mathrm{g}$ poly(dI$\mathrm{dC}$ ) for $1 \mathrm{~h}$ on ice. In the competition experiments, the specific binding of nuclear protein extracts from TM3 cells to the probe was challenged with an excess $(5 \times$ and $25 \times$ molar excess) of unlabeled oligonucleotides corresponding to wild-type (WT) sequences (Pdgfra promoter elements or consensus binding sequences for transcription factors) or to Pdgfra promoter mutants (M2-M10) as indicated. The sequences of the oligonucleotides used in the competition assays are indicated in Table 1. For the supershift experiments, $1.5 \mu \mathrm{g}$ of goat polyclonal anti-SP1 antibody (sc-59x; Santa Cruz Biotechnology, Santa Cruz, CA, USA) and/or rabbit anti-SP3 antibody (sc-644x; Santa Cruz Biotechnology) were added to the binding reaction mixture. Normal goat or rabbit IgGs were used as controls (sc-2028 and sc-2027; Santa Cruz Biotechnology).

\section{Chromatin immunoprecipitation assay}

Chromatin immunoprecipitation (ChIP) assays were performed as described previously (Robert $e t$ al. 2006) with the following modification: TM3 cells were grown in 60-mm dishes until $80 \%$ confluence and sonicated with a Braun-Sonic 1510 Sonicator for eight cycles of 15 s pulses at two output control and constant duty cycle in order to obtain DNA fragments between 200 and $500 \mathrm{bp}$ in size. Cross-linked DNA was immunoprecipitated overnight with rotation at $4{ }^{\circ} \mathrm{C}$ with anti-SP1 (sc-59x Santa Cruz Biotechnology and ab59267 Abcam, Cambridge, MA, USA), anti-SP3 (sc-644x Santa Cruz

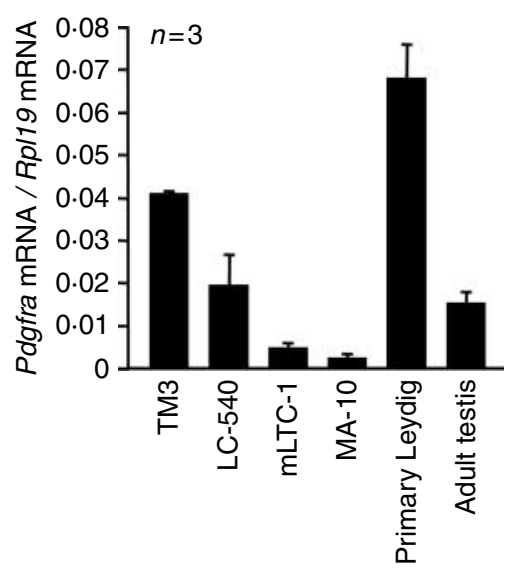

Figure 1 Pdgfra is expressed in the adult mouse testis, primary Leydig cells, and several Leydig cell lines. qPCR was used to detect expression of Pdgfra. Total RNA was isolated from whole testis of adult mice, from primary Leydig cells from immature rats, and from various Leydig cell lines (TM3, LC-540, mLTC-1, and MA-10). Amplification of Rp/19 was used to standardize the results. 


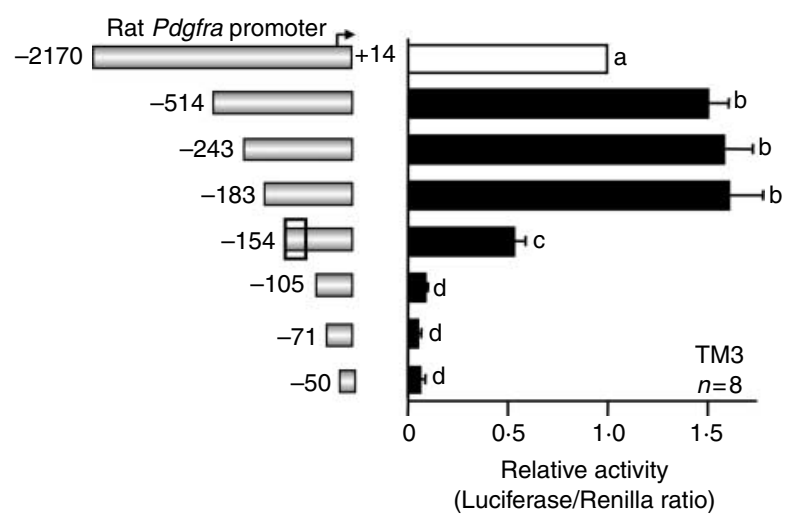

Figure 2 Identification of two regions important for Pdgfra promoter activity in TM3 Leydig cells. TM3 Leydig cells were transfected with various $5^{\prime}$ deletion constructs of the rat $P d g f r a$ promoter (the $5^{\prime}$-end point of each construct is indicated on the left of the graph). Results are shown as relative activity over the $2.2 \mathrm{~kb}$ fragment promoter (mean \pm S.E.M.). A different letter indicates a statistically significant difference.

Biotechnology and ab72594; Abcam), and anti-Histone $\mathrm{H} 3$ as positive control (ab1791 Abcam), and goat or rabbit IgGs (sc-2028, sc-2027 Santa Cruz Biotechnology) as negative controls. PCRs were done using $2 \mu \mathrm{l}$ of input chromatin sample and $5 \mu \mathrm{l}$ of immunoprecipitated chromatin with primers specific for the proximal region $(-184$ to $+14 \mathrm{bp})$ of the rat Pdgfra promoter (sequences provided in Table 1). PCRs were carried out using Vent DNA Polymerase (New England Biolabs, Pickering, ON, Canada) at $94^{\circ} \mathrm{C}$ for 5 min, followed by 32 cycles of $94^{\circ} \mathrm{C}$ for $1 \mathrm{~min}, 62^{\circ} \mathrm{C}$ for $1 \mathrm{~min}$, and $72^{\circ} \mathrm{C}$ for $30 \mathrm{~s}$, and completed by a final extension of $5 \mathrm{~min}$ at $72{ }^{\circ} \mathrm{C}$. The PCR products were analyzed by electrophoresis on a $1.5 \%$ ethidium bromide-stained agarose gel.

\section{In silico analysis}

Analysis of potential regulatory elements in the proximal Pdgfra promoter region $(-154 /-108 \mathrm{bp})$ was performed using bioinformatics software tools MatInspector (http://www.genomatrix.de/cgi-bin/ matinspector/matinspector.pl) and Evolutionary Conserved Regions ECR-Browser (http://ecrbrowser. dcode.org).

\section{Statistical analyses}

Transfection data were analyzed by a one-way ANOVA (SigmaStat Version 2.0, Jadel Corporation, San Rafael, CA, USA). Multiple range comparisons of paired means were then done using a Fisher's LSD test or the Newman-Keuls test. The level of significance was set at $P<0 \cdot 05$. Data are reported as mean \pm s.E.M.

\section{Results}

\section{Expression of Pdgfra in Leydig cell lines}

To characterize the regulatory elements important for Pdgfra expression in Leydig cells, qPCR was first performed to identify a suitable Leydig cell line expressing this gene. Pdgfra mRNA was detected in all samples albeit at different levels (Fig. 1). Pdgfra mRNA was more abundant in primary Leydig cells and in the TM3 Leydig cell line. The TM3 Leydig cell line was chosen for further characterization of the Pdgfra promoter.

\section{Localization of the regulatory elements of the rat Pdgfra promoter}

A $2.2 \mathrm{~kb}(-2170$ to $+14 \mathrm{bp})$ fragment of the Pdgfra promoter was first isolated by PCR from rat genomic DNA. A $2 \cdot 2 \mathrm{~kb}$ fragment was chosen because it sufficiently mimicked the endogenous Pdgfra expression profile in transgenic mice (Zhang et al. 1998). In order to locate the regulatory elements important for Pdgfra transcription in Leydig cells, a series of $5^{\prime}$ progressive deletion constructs were generated from the $2 \cdot 2 \mathrm{~kb}$ fragment and transiently transfected in TM3 cells. Activity of the rat Pdgfra promoter in TM3 Leydig cells was significantly increased with $5^{\prime}$ deletion from -2170 to $-514 \mathrm{bp}$

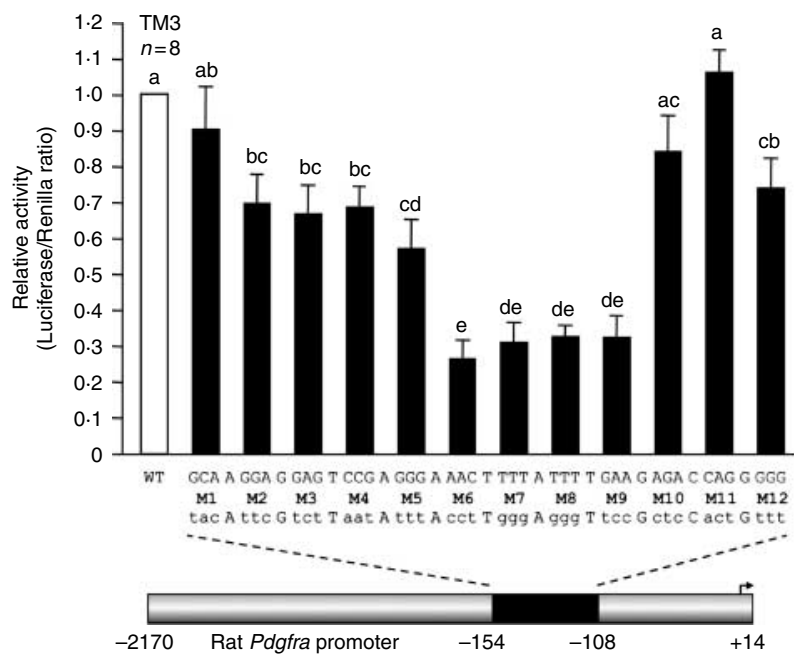

Figure 3 Fine mapping of the -154 to -108 bp region of the rat Pdgfra promoter. TM3 Leydig cells were transfected with either a wild-type (open bar) or a series of rat Pdgfra promoter constructs (solid bars) containing trinucleotide mutations in the -154 / $-108 \mathrm{bp}$ region in the context of the $-2170 \mathrm{bp}$. The wild-type Pdgfra promoter sequence is shown on top and the corresponding mutated nucleotides are shown underneath in lowercase. Results are shown as relative activity over the $-2 \cdot 2 \mathrm{~kb}$ fragment promoter (mean \pm S.E.M.). A different letter indicates a statistically significant difference. 
(Fig. 2). Subsequent $5^{\prime}$ deletions from -514 to -183 bp had no effect on the Pdgfra promoter activity ( $P>0.05$; Fig. 2); however, deletions to -154 bp caused a significant decrease in promoter activity (Fig. 2). Further deletions to $-105 \mathrm{bp}$ abrogated Pdgfra promoter activity in TM3 Leydig cells (Fig. 2). There was no difference in Pdgfra promoter activity of either the -105 or -71 bp reporters as compared with that of the minimal $-50 \mathrm{bp}$ promoter (Fig. 2). These data indicate that Pdgfra promoter activity in TM3 Leydig cells is regulated mainly by two regions: $-183 /-154$ and $-154 /-105 \mathrm{bp}$.

\section{Fine mapping of the -154 to -105 region of the Pdgfra promoter}

To better define the regulatory elements located within the $-154 /-105 \mathrm{bp}$ region responsible for Pdgfra promoter activity, a linker scanning mutagenesis approach was used. Twelve mutants of the Pdgfra promoter, each harboring different trinucleotide mutations in the $-154 /-108 \mathrm{bp}$ region, were generated in the context of the $-2170 \mathrm{bp}$ construct.
These reporter constructs were then transiently transfected in TM3 Leydig cells. As shown in Fig. 3, trinucleotide mutants M2-M9 decreased Pdgfra promoter activity, particularly mutants M6-M9 which encompass a 15-nt A/T-rich region between -135 and $-121 \mathrm{bp}$.

\section{Several proteins bind to the $-157 /-112$ bp region of the Pdgfra promoter}

To determine whether nuclear proteins bind to the $-157 /-112$ bp region of the Pdgfra promoter, EMSAs were performed using nuclear extracts from TM3 Leydig cells and two overlapping radiolabeled probes: probe 1 spanned the region $-157 /-127$ bp of the Pdgfra promoter (Fig. 4A) corresponding to the regions targeted by mutants M2-M5 (Table 1); and probe 2 encompassed the region $-144 /-112$ bp of the Pdgfra promoter (Fig. 4B) corresponding to the sequence mutated in mutants M6-M10 in Fig. 3. Distinct complexes (identified as I, II, III, and IV for probe 1 and V, VI, and VII for probe 2) were observed (lane 2; Fig. 4A and $\mathrm{B}$ ). Increasing the molar concentrations

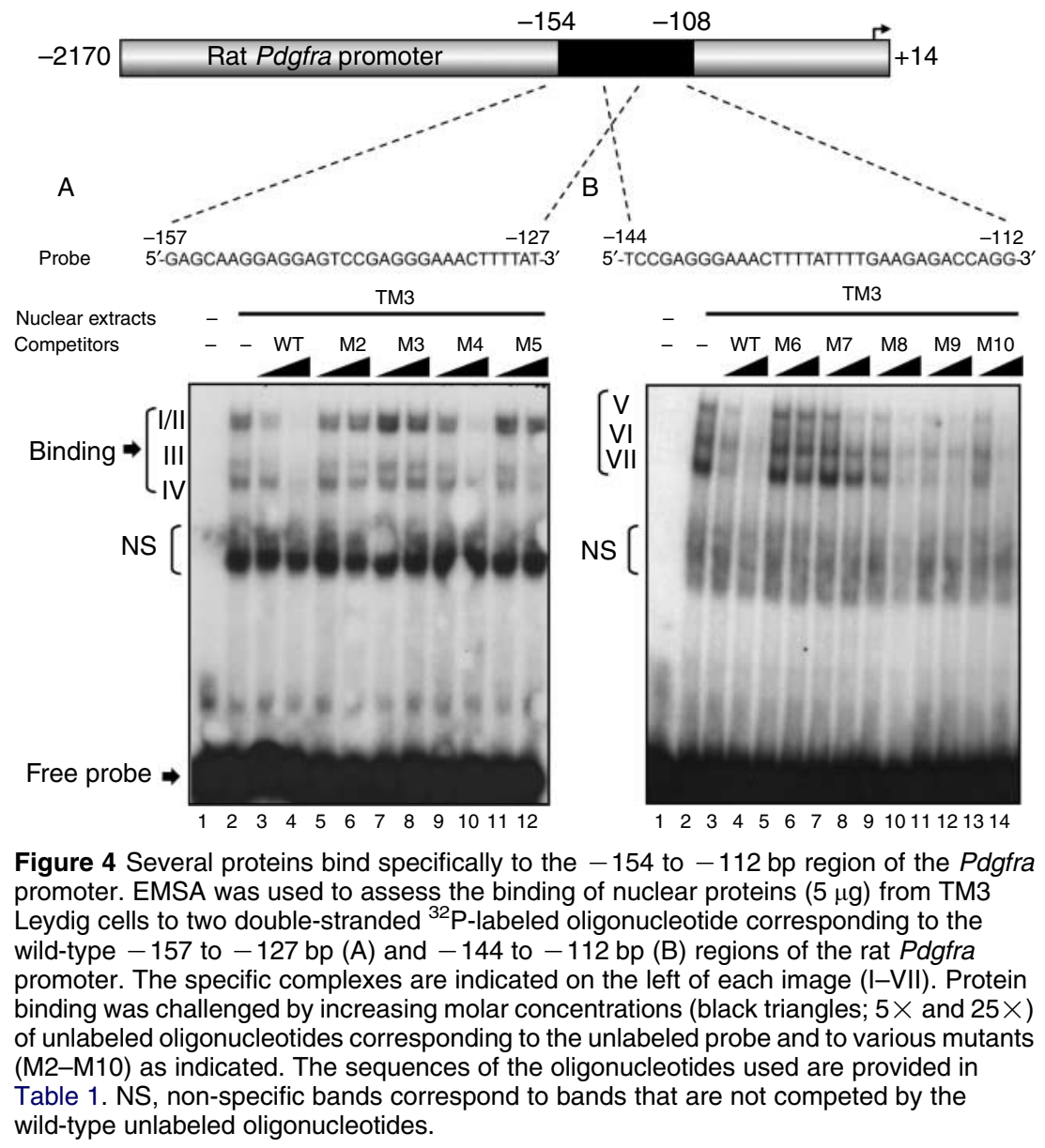


A

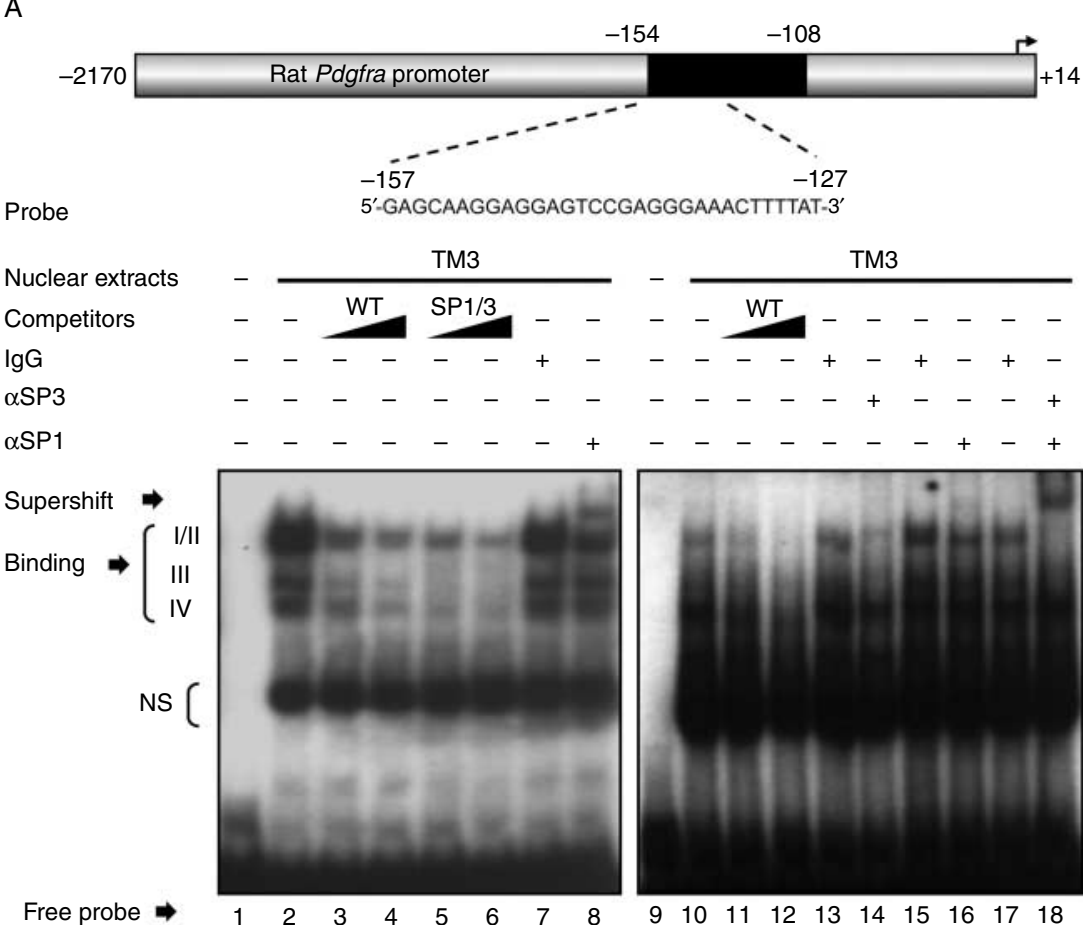

B

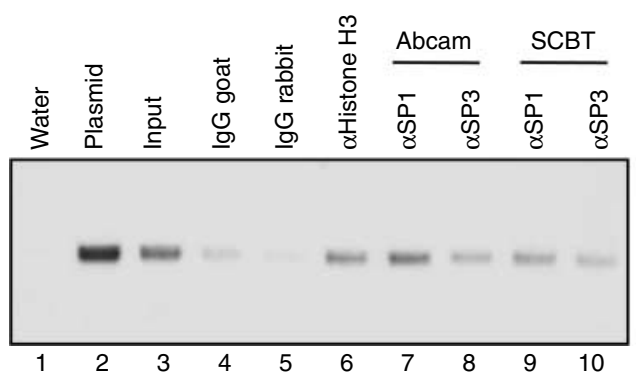

Figure 5 SP1 and SP3 bind to the Pdgfra promoter. (A) EMSA was used to assess the binding of endogenous SP1 and SP3 from TM3 Leydig cell nuclear extracts to a doublestranded ${ }^{32} \mathrm{P}$-labeled oligonucleotide corresponding to the $-157 /-127 \mathrm{bp}$ region of the Pdgfra promoter. Binding was challenged by an excess $(5 \times$ and $25 \times)$ of unlabeled oligonucleotides corresponding to the unlabeled probe (lanes 3-4 and 11-12) or with oligonucleotides containing a consensus SP1/3 binding site (lanes 5 and 6; Giatzakis \& Papadopoulos 2004). The SP1 and SP3 binding were supershifted with SP1 and SP3 antisera ( $\alpha \mathrm{SP} 1, \alpha \mathrm{SP} 3)$. IgG: goat or rabbit IgGs. NS, non-specific bands correspond to bands that are not competed by the wild-type unlabeled oligonucleotides. (B) In vivo recruitment of SP1 and SP3 to the proximal Pdgfra promoter was determined by ChIP assays in TM3 Leydig cells. An aliquot of chromatin preparation before immunoprecipitation (input) was used as positive control. Chromatin was immunoprecipitated with antisera against SP1 ( $\alpha$ SP1) and SP3 ( $\alpha$ SP3). An anti-Histone H3 ( $\alpha$ Histone H3) antiserum was used as a positive control for the ChIP. Preimmune goat and rabbit serum (IgG) were used as negative controls. A 200-bp DNA fragment containing the SP1 and SP3 site within the rat Pdgfra promoter was amplified by PCR. A plasmid containing the rat $P$ dgfra promoter served as a positive control for the PCR while water served as a negative control.

$(5 \times$ and $25 \times)$ of unlabeled oligonucleotide corresponding to the respective probes displaced the protein-DNA complexes (lanes 3 and 4; Fig. 4A and B). Competition experiments were also performed with oligonucleotides harboring trinucleotide mutations (same mutations that were used in the transfections; see Fig. 3 for the sequences). As shown in Fig. 4A and $\mathrm{B}$, oligonucleotides containing mutations M4, M8, 
M9, and M10 were as efficient as the WT probe at competing protein binding. On the other hand, oligonucleotides harboring mutations M2, M3, and M6 could not compete with the probe in the binding assay (Fig. 4A and B). This indicated that mutations M2, M3, and M6 prevented binding of the transcription factors. Oligonucleotides for mutants M5 and M7 competed the formation of specific protein-DNA complexes; M5 blunted the formation of complexes III and IV (Fig. 4A, lanes 11 and 12), while M7 essentially competed complex V (Fig. 4B, lines 7 and 8).

\section{SP1 and SP3 bind to and activate the rat Pdgfra promoter}

Since mutations M4, M5, and M6 decreased Pdgfra promoter activity (Fig. 3), while mutants M5 and M6 also abrogated some protein-DNA binding activities (Fig. 4), the sequence in this region was analyzed in more detail. Mutants M4, M5, and M6 alter the sequence CCGAGGGAAAC, a $\mathrm{G}(\mathrm{A} / \mathrm{C})$-rich sequence that constitutes a potential binding site for members of the ETS (Nye et al. 1992) and SP (Letovsky \& Dynan 1989) families of transcription factors. We therefore tested whether SP1 and/or SP3 bind to the -157/ -127 bp element of the Pdgfra promoter. Oligonucleotides containing a consensus SP1/3 binding site were as efficient as the WT probe at competing protein binding (compare lanes 5 and 6 with lanes 3 and 4 in Fig. 5A). Furthermore, as shown in lanes 8 and 16 of Fig. 5A, addition of an antiserum against the SP1 protein resulted in a supershift of complex I while having no effect on complexes II, III, and IV. Addition of an antiSP3 antibody abrogated complex II (Fig. 5A, lane 14). Finally, addition of antisera for both SP1 and SP3 resulted in a supershift of complexes I and II. Taken together, these data indicate that these complexes I and II correspond to SP1 and SP3 (Fig. 5A, lane 18). Therefore, SP1 and SP3 are present in TM3 nuclear extracts that bind to the Pdgfra promoter.

To confirm the recruitment of SP1 and SP3 to the proximal Pdgfra promoter in vivo, ChIP assays were performed. ChIP was performed with two distinct antisera for each SP1 and SP3. As shown in Fig. 5B, a band of expected size ( $\sim 200 \mathrm{bp}$ ) corresponding to the proximal Pdgfra promoter was detected in the samples immunoprecipitated with the anti-Histone $\mathrm{H} 3$ antibody (positive control for the immunoprecipitation; Fig. 5B, lane 6) as well as in the samples immunoprecipitated with all antisera against SP1 (Fig. 5B, lanes 7 and 9) and SP3 (Fig. 5B, lanes 8 and 10). This indicates that both SP1 and SP3 are associated with the proximal Pdgfra promoter in TM3 Leydig cells.

The role of SP1 and SP3 on Pdgfra promoter activity was assessed by transient transfections in TM3 Leydig cells. As shown in Fig. 6, the activity of the $-2170 \mathrm{bp}$

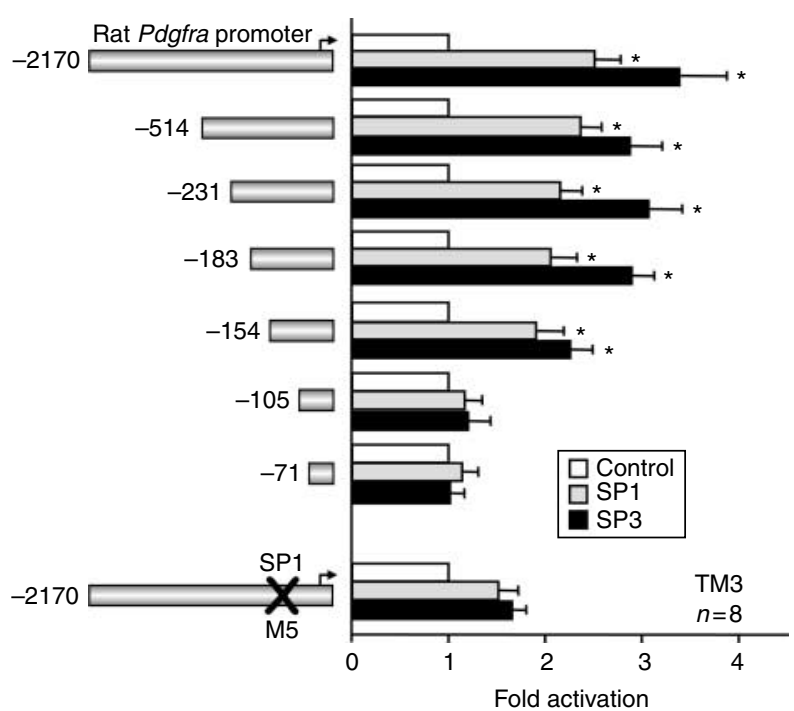

Figure 6 The element at $-138 \mathrm{bp}$ is necessary and sufficient for SP1- and SP3-dependent activation of the Pdgfra promoter. TM3 Leydig cells were co-transfected with various $5^{\prime}$ deletion constructs of the Pdgfra promoter (the $5^{\prime}$-end point of each construct is indicated on the left of the graph) or with a reporter harboring a trinucleotide mutation in the SP1/SP3 binding site at -138 bp (indicated by the large $X$ ) along with either an empty expression vector (open bars) or expression vectors for SP1 (grey bars) and SP3 (black bars). Results are shown as fold activation over control (mean \pm S.E.M.). The asterisk indicates a statistically significant difference from control (empty expression vector).

Pdgfra promoter was increased about threefold in the presence of SP1 or SP3. Combination of SP1 and SP3 did not lead to further activation (data not shown). The SP1- and SP3-mediated transactivation was lost when the region between -154 and -105 bp was deleted, indicating that it contains an SP-responsive element. This $-154 /-105$ bp contains the SP binding site at $-138 \mathrm{bp}$ (Fig. 5). A Pdgfra reporter harboring a mutation in this element (M5) known to prevent binding of SP factors (Figs 4 and 5) in the context of the -2170 bp promoter was only weakly activated by SP1 or SP3, and this activation was not statistically significant $(P>0.05)$. Altogether, these data indicate that SP1 and SP3 activate the Pdgfra promoter by binding to the $\mathrm{G}(\mathrm{C} / \mathrm{A})$ motif at $-138 \mathrm{bp}$.

\section{Potential partners for SP1/3 in the regulation of Pdgfra transcription}

We performed in silico analyses of the $-154 /-108 \mathrm{bp}$ sequence to identify potential regulatory elements and transcription factors that could bind to this region (e.g. complexes III-VII) and act in concert with SP1/3 to regulate Pdgfra transcription in Leydig cells. Several potential transcription factor-binding sites were identified including RBPJ-K, E2F1, HLTF, NFAT, HMX2, 
A

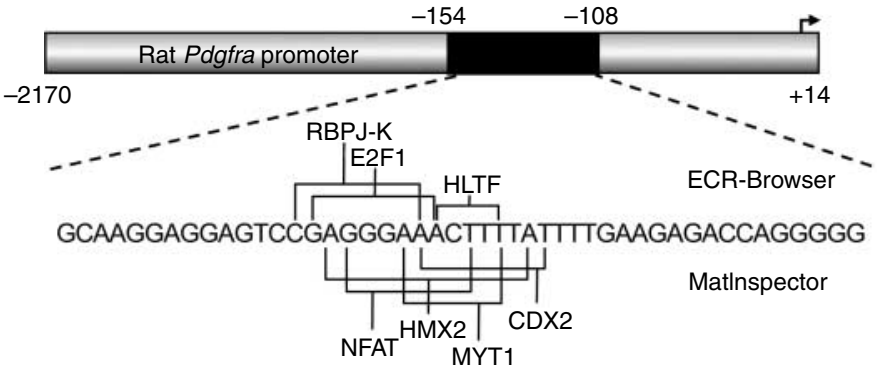

B
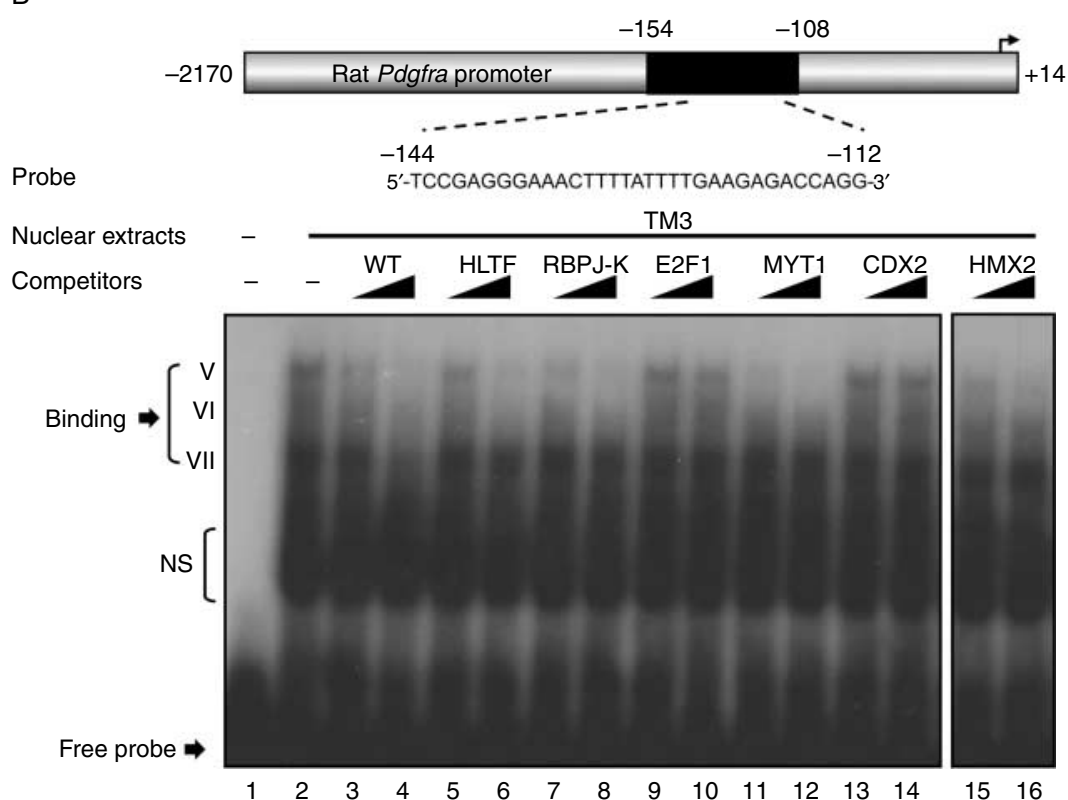

Figure 7 Putative transcription factors regulatory elements in the proximal region of the rat Pdgfra promoter. (A) Schematic representation of the promoter region of the rat Pdgfra gene $(-2170 /+14 \mathrm{bp}$ ) highlighting the -154 to $-108 \mathrm{bp}$ region (solid black rectangle) that was analyzed for potential regulatory elements using ECR-Browser and MatInspector. Putative regulatory elements identified by both methods include the recombination signal binding protein for immunoglobulin kappa $J$ region (RBPJ-K), E2F transcription factor 1 (E2F1), helicase-like transcription factor (HLTF), H6 family homeobox 2 (HMX2), nuclear factor of activated T-cells (NFAT), myelin transcription factor 1 (MYT1), and caudal type homeobox 2 (CDX2). (B) EMSA was performed using nuclear proteins from TM3 Leydig cells to a double-stranded ${ }^{32} \mathrm{P}$-labeled oligonucleotide corresponding to the $-144 /-112$ bp region of the Pdgfra promoter (probe 2). Binding was then challenged by an excess (black triangles; $5 \times$ and $25 \times$ ) of either unlabeled oligonucleotides corresponding to the $-144 /-112$ bp Pdgfra promoter region (WT) or oligonucleotides harboring consensus sequences for the binding of the transcription factors HLTF (Hewetson et al. 2002), RBPJ-K (King et al. 2006), E2F1 (Zhang et al. 2008), MYT1 (Kim \& Hudson 1992), CDX2 (Gendron et al. 2006), and HMX2 (Mennerich et al. 1999). The sequences of the oligonucleotides used are provided in Table 1. NS, non-specific.

MYT1, and CDX2 (Fig. 7A). Oligonucleotides containing consensus sequences for these transcription factors were then used in EMSA/competition experiments. As shown in Fig. 7B and summarized in Table 2, oligonucleotides harboring consensus binding sites for RBPJ-K, HLTF, HMX2, and MYT1 were as efficient as the WT Pdgfra probe at competing the formation of complexes V and VI but had no effect on complex VII.
Oligonucleotides harboring the consensus sequences for CDX2 and E2F1 could not compete any of the complexes (Fig. 7B and Table 2). Next, the presence of RBPJ-K, HLTF, NFAT, HMX2, and MYT1 in Leydig cell lines and their impact on Pdgfra promoter activity were determined. RBPJ-K, HLTF, HMX2, and various NFAT family members (NFATc1, NFATc2, NFATc3, and NFATc5) were detected by RT-PCR in Leydig cell lines 
Table 2 Summary of the results for the EMSA/competition assays, RT-PCR, Pdgfra promoter activation and cooperation with SP1/SP3 for the potential partners

\begin{tabular}{|c|c|c|c|c|c|c|c|c|}
\hline \multirow{2}{*}{$\begin{array}{l}\text { Transcription } \\
\text { factor }\end{array}$} & \multirow{2}{*}{$\begin{array}{l}\text { Consensus } \\
\text { binding } \\
\text { sequence }^{b}\end{array}$} & \multirow[b]{2}{*}{ References } & \multicolumn{3}{|c|}{$\begin{array}{l}\text { Competes binding } \\
\text { to complexes }{ }^{\mathrm{a}}\end{array}$} & \multirow{2}{*}{$\begin{array}{l}\text { Present in } \\
\text { Leydig cell } \\
\text { lines }^{a}\end{array}$} & \multirow{2}{*}{$\begin{array}{l}\text { Activates } \\
\text { Pdgfra } \\
\text { promoter }^{a}\end{array}$} & \multirow{2}{*}{$\begin{array}{l}\text { Cooperates } \\
\text { with SP1 or } \\
\text { SP3 on } \\
\text { Pdgfra } \\
\text { promoter }^{a}\end{array}$} \\
\hline & & & V & VI & VII & & & \\
\hline $\begin{array}{l}\text { HLTF } \\
\text { Helicase-like } \\
\text { transcription factor }\end{array}$ & MCWTNK & $\begin{array}{l}\text { Hewetson } \\
\text { et al. (2002) }\end{array}$ & $y$ & $y$ & $\mathrm{n}$ & $y$ & $\mathrm{n}$ & $\mathrm{n}$ \\
\hline $\begin{array}{l}\text { RBPJ-K } \\
\text { Recombination signal binding } \\
\text { protein for immunoglobulin } \\
\text { kappa J region }\end{array}$ & TTCCCACG & Tun et al. (1994) & $\mathrm{y}$ & $y$ & $n$ & $y$ & $\mathrm{n}$ & $\mathrm{n}$ \\
\hline $\begin{array}{l}\mathrm{HMX} 2 \\
\mathrm{H} 6 \text { family homeobox } 2\end{array}$ & $\begin{array}{l}\text { RGRSAAAC- } \\
\text { GTTTC }\end{array}$ & $\begin{array}{l}\text { Mennerich et al. } \\
\text { (1999) }\end{array}$ & $y$ & $\mathrm{y}$ & $\mathrm{n}$ & $y$ & $\mathrm{n}$ & $\mathrm{n}$ \\
\hline $\begin{array}{l}\text { MYT1 } \\
\quad \text { Myelin transcription factor } 1\end{array}$ & AAAGTTT & $\begin{array}{l}\text { Kim \& Hudson } \\
\quad(1992)\end{array}$ & $\mathrm{y}$ & $y$ & $\mathrm{n}$ & $\mathrm{n}$ & ND & ND \\
\hline $\begin{array}{l}\text { CDX2 } \\
\text { Caudal type homeobox } 2\end{array}$ & MTTTATR & $\begin{array}{l}\text { Margalit et al. } \\
\text { (1993) }\end{array}$ & $\mathrm{n}$ & $\mathrm{n}$ & $\mathrm{n}$ & ND & ND & ND \\
\hline
\end{tabular}

${ }^{a} y$, yes; $n$, no; ND, not determined.

${ }^{b} \mathrm{M}$ : A or C; W: A or T; N: A, C, G, or T; K: G or T; S: C or G; R: G or A; H: A, T, or C.

(Table 2). However, none of the factors tested (RBPJ-K, HLTF, and HMX2) could activate the Pdgfra promoter either alone or in combination with SP1/SP3 when transiently transfected in TM3 Leydig cells (Table 2).

\section{Discussion}

In the rat, human, and mouse testis, FLC and ALC express PDGFRA (Gnessi et al. 1992, 1995, 2000, Schmahl et al. 2008). Using qPCR, we detected different levels of Pdgfra mRNA in the testis of the adult mouse, primary Leydig cells from immature rats, and in TM3, LC-540, mLTC-1, and MA-10 Leydig cell lines. The presence of the Pdgfra mRNA in the Leydig cell lines indicates that they possess the transcriptional regulators required for its expression. In the present study, we used the TM3 cell line as a model to decipher the transcriptional regulation of the Pdgfra gene in Leydig cells.

Our Pdgfra promoter analysis in TM3 Leydig cells revealed an increase in promoter activity when the $5^{\prime}$ end of the -2170 Pdgfra promoter fragment was deleted to $-514 \mathrm{bp}$. The increase in promoter activity may have been due to elimination of potential repressive sequences upstream of $-514 \mathrm{bp}$. Kitami et al. (1995) reported a similar increase in Pdgfra promoter activity in VSMC following the deletion of the -1682 to -1428 bp region. They suggested that the alternating d(TG) $n$-type purine-pyrimidine dinucleotide repeats contained in this region were responsible for the repression (Naylor \& Clark 1990, Kitami et al. 1995). In addition, in silico analysis of the -2170 to -514 bp region of the Pdgfra promoter (MatInspector) revealed the presence of potential binding sites for several transcriptional repressors including ZNF219 (Sakai et al. 2003), BCL6 (Chang et al. 1996), GFI1 (Zweidler-Mckay et al. 1996), EN1 (engrailed homeobox 1; Jaynes \& O'Farrell 1991), and Kaiso (Prokhortchouk et al. 2001). It is therefore likely that some of these transcriptional repressors along with the distal sequence $\mathrm{d}$ (TG) 30 repeats present in the Pdgfra promoter act to ensure an inhibitory control of Pdgfra gene expression in the TM3 Leydig cells. Deletions between -514 and -183 bp had no impact on Pdgfra promoter activity, indicating that the proximal $197 \mathrm{bp}$ $(-183$ to $+14 \mathrm{bp})$ contains all the necessary regulatory elements for Pdgfra expression in TM3 Leydig cells. This is consistent with data for the human PDGFRA promoter where a proximal $-464 \mathrm{bp}$ fragment was found to be sufficient to confer maximal promoter activity in human teratocarcinoma and mouse 3T3 cells (Afink et al. 1995).

Our promoter deletion approach identified a first region, from -183 to $-154 \mathrm{bp}$, as critical to maintain high Pdgfra promoter activity in TM3 Leydig cells indicating the presence of important regulatory elements. In a previous study, using DNase I footprinting and EMSA, the proximal promoter $(-220 \mathrm{bp})$ was 
found to contain an enhancer core sequence that is recognized by members of the C/EBP family of transcription factors (Fukuoka et al. 1999, Kitami et al. 1999, Yang et al. 2001, Afink et al. 2004). In VSMC, $\mathrm{C} / \mathrm{EBP} \delta$ was shown to up-regulate Pdgfra transcription, whereas C/EBP $\beta$ repressed it (Fukuoka et al. 1999, Kitami et al. 1999, Yang et al. 2001, Afink et al. 2004). We obtained similar findings in TM3 Leydig cells where both $\mathrm{C} / \mathrm{EBP} \alpha$ and $\delta$ increased Pdgfra promoter activity, whereas $\mathrm{C} / \mathrm{EBP} \beta$ acted as a repressor (data not shown). In testicular Leydig cells and in ovarian granulosa cells, both human chorionic gonadotropin (hCG) and LH increase C/EBP $\beta$ levels (Sterneck et al. 1997, Nalbant et al. 1998). The same treatment, however, represses PDGFRA expression in human granulosa-luteal cells (Hwu et al. 2009) in agreement with a repressing role for $\mathrm{C} / \mathrm{EBP} \beta$ in Pdgfra expression. Immature and mature Leydig cells isolated from 20- to 70-day-old rats exclusively express C/EBP $\beta$ (Nalbant et al. 1998). However, no data are available regarding the expression of $\mathrm{C} / \mathrm{EBP}$ family members in Leydig cells during the pre-natal period. Therefore, a role for other C/EBP family members $(\alpha, \delta$, and $\sigma)$ in the activation of Pdgfra transcription in FLC in utero cannot be ruled out.

A second region, from -154 to $-105 \mathrm{bp}$, was also found to be essential for Pdgfra promoter activity in TM3 Leydig cells. Site-directed mutagenesis of this region in the context of the $-2170 \mathrm{bp}$ construct revealed the importance of a $\mathrm{G}(\mathrm{C} / \mathrm{A})$-rich and a $\mathrm{T} / \mathrm{A}$ rich motif. Several protein complexes were found to be associated with these motifs. Mutations that altered the core sequence TCCGAGGGAAAC prevented binding of the nuclear proteins and significantly decreased Pdgfra promoter activity in TM3 cells. Interestingly, this motif is similar to binding sites for members of the ETS (Nye et al. 1992), SP (Letovsky \& Dynan 1989), and NFAT (Rao et al. 1997) families of transcription factors. Our transactivation assays revealed that SP1 and SP3 activate the Pdgfra promoter by about threefold. This activation was lost with a deletion of the -154 to $-105 \mathrm{bp}$ region or with a mutation of the SP binding site at $-138 \mathrm{bp}$. Binding of SP1 and SP3 to this element was indeed confirmed by the use of anti-SP1 and anti-SP3 antisera in EMSA, which led to supershift of two of the complexes. Both SP1 and SP3 have a $>90 \%$ DNA sequence homology and are known to bind to the same DNA element with similar affinities (Li et al. 2004). Bonello \& Khachigian (2004) also reported the implication of SP1 in Pdgfra promoter activity in VSMC. SP1-dependent activation of the Pdgfra promoter in these cells was found to involve an atypical recognition element located $\sim 40$ bp $3^{\prime}$ of the SP1/3 element we have identified in TM3 Leydig cells (Fig. 8). This atypical element might in fact be responsible for the weak activation by SP1/3 of the full-length Pdgfra reporter harboring a mutation (M5) in the SP binding site at $-138 \mathrm{bp}$. Altogether, these findings indicate that the involvement of SP1 and SP3 might represent a conserved mechanism for Pdgfra expression in several tissues.

In addition to directly binding to and activating the Pdgfra promoter, the contribution of SP1 and SP3 in Pdgfra transcription is of interest since it could represent an alternative mechanism for the hormonal regulation of Pdgfra in Leydig cells. Pdgfra expression is known to be regulated by various hormones, including retinoic acid, estrogens, glucocorticoids, and cAMP in different cell types (Tsukamoto et al. 1994, Afink et al. 1995, Warshamana et al. 1998, Thuillier et al. 2003). Interestingly, SP1 and SP3 are known to interact with the receptors for these hormones and to act as their transcriptional effectors (Safe \& Kim 2004).

Although SP1 and SP3 are ubiquitously expressed, they nonetheless contribute to tissue- and cell-specific gene expression through interactions and co-operations with cell-restricted transcription factors. Consistent with this, we found that SP1 and SP3 were responsible for only two of the four complexes detected with the probe containing the $\mathrm{G}(\mathrm{A} / \mathrm{C})$-rich motif. To identify potential partners that act in concert with $\mathrm{SP} 1 / 3$ in Pdgfra transcription in Leydig cells, we performed in silico analyses of the $-154 / 108$ bp sequence, EMSA/competition assays, and RT-PCR. We identified several potential candidates including RBPJ-K, HLTF, HMX2, and NFAT family members (NFATc1, NFATc2, NFATc3, and NFATc5). When tested in transactivation assays, RBPJ-K, HLTF, and HMX2 did not activate the Pdgfra promoter either alone or in concert with SP1/3 in these in vitro conditions. We cannot, however, exclude the

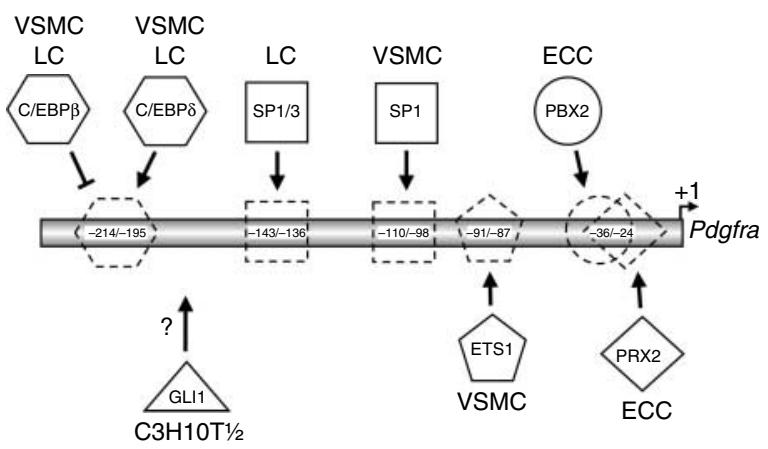

Figure 8 Schematic representation of regulatory elements identified in the proximal region of the Pdgfra promoter. In human, rat and mouse, Pdgfra transcription is modulated by C/EBP family members (Fukuoka et al. 1999, Yang et al. 2001, Afink et al. 2004), SP1 and SP3 (Bonello \& Khachigian 2004; our present data), GLI1 (Xie et al. 2001), ETS1 (Bonello et al. 2005), PBX2 (Joosten et al. 2002), and PRX2 (Joosten et al. 2002) via regulatory elements present in the proximal promoter region $(-214$ to $-24 \mathrm{bp})$. The transcription factors will bind to their respective response element causing either activation (solid arrows) or repression (blunted line) of Pdgfra expression. The GLI1 responsive element remains to be identified (question mark). VSMC, vascular smooth muscle cells; LC, Leydig cells; ECC, F9 embryonic carcinoma cells; C3H $10 \mathrm{~T} 1 / 2$, pre-adipocytes. 
possibility that these factors might contribute to Pdgfra transcription in Leydig cells in vivo. In addition, members of the ETS and NFAT families are also interesting candidates since they are expressed in Leydig cells and can bind to GA-rich sequences (Rao et al. 1997, Giatzakis et al. 2007).

The transcriptional mechanisms regulating Pdgfra expression in Leydig cells had not been described, and, in other cell types, only a handful of transcription factors have been identified as regulators of Pdgfra expression (summarized in Fig. 8). Our study is the first to report a detailed analysis of the Pdgfra regulatory region in Leydig cells, which led to the identification of a role for the transcription factors SP1 and SP3. Both $S p 1$ and $S p 3$ genes have been inactivated in the mouse. SP1- or SP3deficient mice die embryonically or at birth (reviewed in Zhao \& Meng (2005)) impeding the assessment of a direct role for these transcriptional regulators in Pdgfra expression in Leydig cells in vivo. Our ChIP assays nonetheless confirmed that SP1 and SP3 are associated with the proximal $P d g$ fra promoter in a native chromatin context in TM3 Leydig cells thus supporting a role for these factors in in vivo Pdgfra transcription.

\section{Declaration of interest}

The authors declare that there is no conflict of interest that could be perceived as prejudicing the impartiality of the research reported.

\section{Funding}

J J T holds a Chercheur-boursier Junior 2 scholarship from the Fonds de la recherche en santé du Québec. This work was supported by the Canadian Institutes of Health Research (grant number MOP81387 to J J T).

\section{Acknowledgements}

We are grateful to Dr Mario Ascoli for the MA-10 Leydig cell line and to Dr Robert Viger for the SP1 expression vector. Dr Charlotte Dubé, Dr Luc J Martin, Véronique Champagne, Catherine Brousseau, and Dr Nicholas Robert are thanked for their assistance with some of the Pdgfra deletion constructs, RT-PCR for NFAT family members, and preparation of primary Leydig cell cultures.

\section{References}

Afink GB, Nister M, Stassen BH, Joosten PH, Rademakers PJ, BongcamRudloff E, Van Zoelen EJ \& Mosselman S 1995 Molecular cloning and functional characterization of the human platelet-derived growth factor $\alpha$ receptor gene promoter. Oncogene 10 1667-1672.

Afink G, Westermark UK, Lammerts E \& Nister M 2004 C/EBP is an essential component of PDGFRA transcription in MG-63 cells. Biochemical and Biophysical Research Communications 315 313-318. (doi:10.1016/j.bbrc.2004.01.056)

Ascoli M 1981 Characterization of several clonal lines of cultured Leydig tumor cells: gonadotropin receptors and steroidogenic responses. Endocrinology 108 88-95. (doi:10.1210/endo-108-1-88)
Basciani S, Mariani S, Spera G \& Gnessi L 2010 Role of plateletderived growth factors in the testis. Endocrine Reviews 31 916-939. (doi:10.1210/er.2010-0004)

Bonello MR \& Khachigian LM 2004 Fibroblast growth factor-2 represses platelet-derived growth factor receptor- $\alpha$ (PDGFR- $\alpha$ ) transcription via ERK1/2-dependent Sp1 phosphorylation and an atypical cis-acting element in the proximal PDGFR- $\alpha$ promoter. Journal of Biological Chemistry 279 2377-2382. (doi:10.1074/jbc. M308254200)

Bonello MR, Bobryshev YV \& Khachigian LM 2005 Peroxide-inducible Ets-1 mediates platelet-derived growth factor receptor- $\alpha$ gene transcription in vascular smooth muscle cells. American Journal of Pathology 167 1149-1159. (doi:10.1016/S0002-9440(10)61203-5)

Brennan J, Tilmann C \& Capel B 2003 Pdgfr- $\alpha$ mediates testis cord organization and fetal Leydig cell development in the XY gonad. Genes and Development 17 800-810. (doi:10.1101/gad.1052503)

Buehr M, Gu S \& McLaren A 1993 Mesonephric contribution to testis differentiation in the fetal mouse. Development 117 273-281.

Chang CC, Ye BH, Chaganti RS \& Dalla-Favera R 1996 BCL-6, a $\mathrm{POZ}$ /zinc-finger protein, is a sequence-specific transcriptional repressor. PNAS 93 6947-6952. (doi:10.1073/pnas.93.14.6947)

Cool J \& Capel B 2009 Mixed signals: development of the testis. Seminars in Reproductive Medicine 27 5-13. (doi:10.1055/s-00281108005)

Davidoff MS, Middendorff R, Enikolopov G, Riethmacher D, Holstein AF \& Muller D 2004 Progenitor cells of the testosterone-producing Leydig cells revealed. Journal of Cell Biology 167 935-944. (doi:10. $1083 /$ jcb.200409107)

Fukuoka T, Kitami Y, Okura T \& Hiwada K 1999 Transcriptional regulation of the platelet-derived growth factor $\alpha$ receptor gene via CCAAT/enhancer-binding protein-delta in vascular smooth muscle cells. Journal of Biological Chemistry 274 25576-25582. (doi:10.1074/ jbc.274.36.25576)

Ge RS, Dong Q, Sottas CM, Papadopoulos V, Zirkin BR \& Hardy MP 2006 In search of rat stem Leydig cells: identification, isolation, and lineage-specific development. PNAS 103 2719-2724. (doi:10.1073/ pnas.0507692103)

Gendron FP, Mongrain S, Laprise P, McMahon S, Dubois CM, Blais M, Asselin C \& Rivard N 2006 The CDX2 transcription factor regulates furin expression during intestinal epithelial cell differentiation. American Journal of Physiology. Gastrointestinal and Liver Physiology 290 G310-G318. (doi:10.1152/ajpgi.00217.2005)

Giatzakis C \& Papadopoulos V 2004 Differential utilization of the promoter of peripheral-type benzodiazepine receptor by steroidogenic versus nonsteroidogenic cell lines and the role of Sp1 and Sp3 in the regulation of basal activity. Endocrinology 145 1113-1123. (doi:10.1210/en.2003-1330)

Giatzakis C, Batarseh A, Dettin L \& Papadopoulos V 2007 The role of Ets transcription factors in the basal transcription of the translocator protein (18 kDa). Biochemistry 46 4763-4774. (doi:10. 1021/bi062208o)

Gnessi L, Emidi A, Farini D, Scarpa S, Modesti A, Ciampani T, Silvestroni L \& Spera G 1992 Rat Leydig cells bind platelet-derived growth factor through specific receptors and produce plateletderived growth factor-like molecules. Endocrinology 130 2219-2224. (doi:10.1210/en.130.4.2219)

Gnessi L, Emidi A, Jannini EA, Carosa E, Maroder M, Arizzi M, Ulisse S \& Spera G 1995 Testicular development involves the spatiotemporal control of PDGFs and PDGF receptors gene expression and action. Journal of Cell Biology 131 1105-1121. (doi:10.1083/jcb.131.4.1105)

Gnessi L, Basciani S, Mariani S, Arizzi M, Spera G, Wang C, Bondjers C, Karlsson L \& Betsholtz C 2000 Leydig cell loss and spermatogenic arrest in platelet-derived growth factor (PDGF)-A-deficient mice. Journal of Cell Biology 149 1019-1026. (doi:10.1083/jcb.149.5.1019)

Guigon CJ, Coudouel N, Mazaud-Guittot S, Forest MG \& Magre S 2005 Follicular cells acquire Sertoli cell characteristics after oocyte loss. Endocrinology 146 2992-3004. (doi:10.1210/en.2005-0045) 
Haider SG 2004 Cell biology of Leydig cells in the testis. International Review of Cytology 233 181-241. (doi:10.1016/S00747696(04)33005-6)

Hewetson A, Hendrix EC, Mansharamani M, Lee VH \& Chilton BS 2002 Identification of the RUSH consensus-binding site by cyclic amplification and selection of targets: demonstration that RUSH mediates the ability of prolactin to augment progesteronedependent gene expression. Molecular Endocrinology 16 2101-2112. (doi:10.1210/me.2002-0064)

Hwu YM, Li SH, Lee RK, Lin MH, Tsai YH \& Yeh TS 2009 Luteinizing hormone increases platelet-derived growth factor-D gene expression in human granulosa-luteal cells. Fertility and Sterility 92 2065-2068. (doi:10.1016/j.fertnstert.2009.05.064)

Jaynes JB \& O'Farrell PH 1991 Active repression of transcription by the engrailed homeodomain protein. EMBO Journal 10 1427-1433.

Joosten PH, Toepoel M, van Oosterhout D, Afink GB \& van Zoelen EJ 2002 A regulating element essential for PDGFRA transcription is recognized by neural tube defect-associated PRX homeobox transcription factors. Biochimica et Biophysica Acta 1588 254-260.

Karl J \& Capel B 1998 Sertoli cells of the mouse testis originate from the coelomic epithelium. Developmental Biology 203 323-333. (doi:10. 1006/dbio.1998.9068)

Kim JG \& Hudson LD 1992 Novel member of the zinc finger superfamily: a C2-HC finger that recognizes a glia-specific gene. Molecular and Cellular Biology 12 5632-5639.

King IN, Kathiriya IS, Murakami M, Nakagawa M, Gardner KA, Srivastava D \& Nakagawa O 2006 Hrt and Hes negatively regulate Notch signaling through interactions with RBP-Jkappa. Biochemical and Biophysical Research Communications 345 446-452. (doi:10.1016/ j.bbrc.2006.04.097)

Kitami Y, Inui H, Uno S \& Inagami T 1995 Molecular structure and transcriptional regulation of the gene for the platelet-derived growth factor $\alpha$ receptor in cultured vascular smooth muscle cells. Journal of Clinical Investigation 96 558-567. (doi:10.1172/JCI118068)

Kitami Y, Fukuoka T, Hiwada K \& Inagami T 1999 A high level of CCAAT-enhancer binding protein-delta expression is a major determinant for markedly elevated differential gene expression of the platelet-derived growth factor- $\alpha$ receptor in vascular smooth muscle cells of genetically hypertensive rats. Circulation Research 84 64-73.

Letovsky J \& Dynan WS 1989 Measurement of the binding of transcription factor Spl to a single GC box recognition sequence. Nucleic Acids Research 17 2639-2653. (doi:10.1093/nar/17.7.2639)

Li L, He S, Sun JM \& Davie JR 2004 Gene regulation by Sp1 and Sp3. Biochemistry and Cell Biology 82 460-471. (doi:10.1139/o04-045)

Lobo MV, Arenas MI, Alonso FJ, Gomez G, Bazan E, Paino CL, Fernandez E, Fraile B, Paniagua R, Moyano A et al. 2004 Nestin, a neuroectodermal stem cell marker molecule, is expressed in Leydig cells of the human testis and in some specific cell types from human testicular tumours. Cell and Tissue Research 316 369-376. (doi:10. 1007/s00441-003-0848-4)

Margalit Y, Yarus S, Shapira E, Gruenbaum Y \& Fainsod A 1993 Isolation and characterization of target sequences of the chicken CdxA homeobox gene. Nucleic Acids Research 21 4915-4922. (doi:10. 1093/nar/21.21.4915)

Martin LJ \& Tremblay JJ 2005 The human 3ß-hydroxysteroid dehydrogenase $/ \Delta^{5}-\Delta^{4}$ isomerase type 2 promoter is a novel target for the immediate early orphan nuclear receptor NUR77 in steroidogenic cells. Endocrinology 146 861-869. (doi:10.1210/en. 2004-0859)

Martin LJ, Boucher N, Brousseau C \& Tremblay JJ 2008 The orphan nuclear receptor NUR77 regulates hormone-induced StAR transcription in Leydig cells through a cooperation with CaMKI. Molecular Endocrinology 22 2021-2037. (doi:10.1210/me.2007-0370)

Mayerhofer A, Seidl K, Lahr G, Bitter-Suermann D, Christoph A, Barthels D, Wille W \& Gratzl M 1992 Leydig cells express neural cell adhesion molecules in vivo and in vitro. Biology of Reproduction $\mathbf{4 7}$ 656-664. (doi:10.1095/biolreprod47.4.656)
Mennerich D, Hoffmann S, Hadrys T, Arnold HH \& Bober E 1999 Two highly related homeodomain proteins, Nkx5-1 and Nkx5-2, display different DNA binding specificities. Biological Chemistry 380 10411048. (doi:10.1515/BC.1999.130)

Merchant-Larios H \& Moreno-Mendoza N 1998 Mesonephric stromal cells differentiate into Leydig cells in the mouse fetal testis. Experimental Cell Research 244 230-238. (doi:10.1006/excr. 1998.4215)

Nalbant D, Williams SC, Stocco DM \& Khan SA 1998 Luteinizing hormone-dependent gene regulation in Leydig cells may be mediated by CCAAT/enhancer-binding protein- $\beta$. Endocrinology 139 272-279. (doi:10.1210/en.139.1.272)

Naylor LH \& Clark EM 1990 d(TG)n.d(CA)n sequences upstream of the rat prolactin gene form Z-DNA and inhibit gene transcription. Nucleic Acids Research 18 1595-1601. (doi:10.1093/nar/18.6.1595)

Nikula H, Koskimies P, El-Hefnawy T \& Huhtaniemi I 2001 Functional characterization of the basal promoter of the murine LH receptor gene in immortalized mouse Leydig tumor cells. Journal of Molecular Endocrinology 26 21-29. (doi:10.1677/jme.0.0260021)

Nye JA, Petersen JM, Gunther CV, Jonsen MD \& Graves BJ 1992 Interaction of murine ets-1 with GGA-binding sites establishes the ETS domain as a new DNA-binding motif. Genes and Development 6 975-990. (doi:10.1101/gad.6.6.975)

Prokhortchouk A, Hendrich B, Jorgensen H, Ruzov A, Wilm M, Georgiev G, Bird A \& Prokhortchouk E 2001 The p120 catenin partner Kaiso is a DNA methylation-dependent transcriptional repressor. Genes and Development 15 1613-1618. (doi:10.1101/gad. 198501)

Rao A, Luo C \& Hogan PG 1997 Transcription factors of the NFAT family: regulation and function. Annual Review of Immunology $\mathbf{1 5}$ 707-747. (doi:10.1146/annurev.immunol.15.1.707)

Robert NM, Martin LJ \& Tremblay JJ 2006 The orphan nuclear receptor NR4A1 regulates Insulin-like 3 gene transcription in Leydig cells. Biology of Reproduction 74 322-330. (doi:10.1095/biolreprod. $105.044560)$

Safe S \& Kim K 2004 Nuclear receptor-mediated transactivation through interaction with Sp proteins. Progress in Nucleic Acid Research and Molecular Biology 77 1-36. (doi:10.1016/S00796603(04)77001-4)

Sakai T, Hino K, Wada S \& Maeda H 2003 Identification of the DNA binding specificity of the human ZNF219 protein and its function as a transcriptional repressor. DNA Research 10 155-165. (doi:10.1093/ dnares/10.4.155)

Scherrer SP, Rice DA \& Heckert LL 2002 Expression of steroidogenic factor 1 in the testis requires an interactive array of elements within its proximal promoter. Biology of Reproduction 67 1509-1521. (doi:10. 1095/biolreprod.102.006932)

Schmahl J, Eicher EM, Washburn LL \& Capel B 2000 Sry induces cell proliferation in the mouse gonad. Development 127 65-73.

Schmahl J, Rizzolo K \& Soriano P 2008 The PDGF signaling pathway controls multiple steroid-producing lineages. Genes and Development 22 3255-3267. (doi:10.1101/gad.1723908)

Schreiber E, Matthias P, Muller MM \& Schaffner W 1989 Rapid detection of octamer binding proteins with 'mini-extracts', prepared from a small number of cells. Nucleic Acids Research $\mathbf{1 7}$ 6419. (doi:10.1093/nar/17.15.6419)

Schwarzenbach H, Chakrabarti G, Paust HJ \& Mukhopadhyay AK 2004 Gonadotropin-mediated regulation of the murine VEGF expression in MA-10 Leydig cells. Journal of Andrology 25 128-139.

Sheng Y, Li J, Dufau ML \& Tsai-Morris CH 2005 The gonadotropinregulated long-chain acyl CoA synthetase gene: a novel downstream Sp1/Sp3 binding element critical for transcriptional promoter activity. Gene 360 20-26. (doi:10.1016/j.gene.2005.07.006)

Sterneck E, Tessarollo L \& Johnson PF 1997 An essential role for $\mathrm{C} / \mathrm{EBP} \beta$ in female reproduction. Genes and Development 11 2153-2162. (doi:10.1101/gad.11.17.2153)

Thuillier R, Wang Y \& Culty M 2003 Prenatal exposure to estrogenic compounds alters the expression pattern of platelet-derived growth 
factor receptors $\alpha$ and $\beta$ in neonatal rat testis: identification of gonocytes as targets of estrogen exposure. Biology of Reproduction 68 867-880. (doi:10.1095/biolreprod.102.009605)

Tremblay JJ \& Viger RS 1999 Transcription factor GATA-4 enhances Müllerian inhibiting substance gene transcription through a direct interaction with the nuclear receptor SF-1. Molecular Endocrinology 13 1388-1401. (doi:10.1210/me.13.8.1388)

Tsukamoto T, Matsui T, Takaishi T, Ito M, Fukase M \& Chihara K 1994 Retinoic acid differentially affects platelet-derived growth factor and epidermal growth factor-regulated cell growth of mouse osteoblastlike cells. Cell Growth and Differentiation 5 207-212.

Tun T, Hamaguchi Y, Matsunami N, Furukawa T, Honjo T \& Kawaichi M 1994 Recognition sequence of a highly conserved DNA binding protein RBP-Jkappa. Nucleic Acids Research 22 965-971. (doi:10. 1093/nar/22.6.965)

Warshamana GS, Martinez S, Lasky JA, Corti M \& Brody AR 1998 Dexamethasone activates expression of the PDGF- $\alpha$ receptor and induces lung fibroblast proliferation. American Journal of Physiology 274 L499-L507.

Xie J, Aszterbaum M, Zhang X, Bonifas JM, Zachary C, Epstein E \& McCormick F 2001 A role of PDGFR $\alpha$ in basal cell carcinoma proliferation. PNAS 98 9255-9259. (doi:10.1073/pnas. 151173398)

Yang ZH, Kitami Y, Takata Y, Okura T \& Hiwada K 2001 Targeted overexpression of CCAAT/enhancer-binding protein-delta evokes enhanced gene transcription of platelet-derived growth factor $\alpha$-receptor in vascular smooth muscle cells. Circulation Research $\mathbf{8 9}$ 503-508. (doi:10.1161/hh1801.096265)
Zhang XQ, Afink GB, Svensson K, Jacobs JJ, Gunther T, ForsbergNilsson K, van Zoelen EJ, Westermark B \& Nister M 1998 Specific expression in mouse mesoderm- and neural crestderived tissues of a human PDGFRA promoter/lacZ transgene. Mechanisms of Development 70 167-180. (doi:10.1016/S09254773(97)00190-1)

Zhang L, Sheppard OR, Shah AM \& Brewer AC 2008 Positive regulation of the NADPH oxidase NOX4 promoter in vascular smooth muscle cells by E2F. Free Radical Biology \& Medicine $\mathbf{4 5}$ 679-685. (doi:10.1016/j.freeradbiomed.2008.05.019)

Zhao C \& Meng A 2005 Sp1-like transcription factors are regulators of embryonic development in vertebrates. Development, Growth and Differentiation 47 201-211. (doi:10.1111/j.1440-169X.2005. 00797.x)

Zheng N, Fraenkel E, Pabo CO \& Pavletich NP 1999 Structural basis of DNA recognition by the heterodimeric cell cycle transcription factor E2F-DP. Genes and Development 13 666-674. (doi:10.1101/gad. 13.6.666)

Zweidler-Mckay PA, Grimes HL, Flubacher MM \& Tsichlis PN 1996 Gfi1 encodes a nuclear zinc finger protein that binds DNA and functions as a transcriptional repressor. Molecular and Cellular Biology 16 4024-4034.

Received in final form 24 January 2011

Accepted 2 February 2011

Made available online as an Accepted Preprint 2 February 2011 